
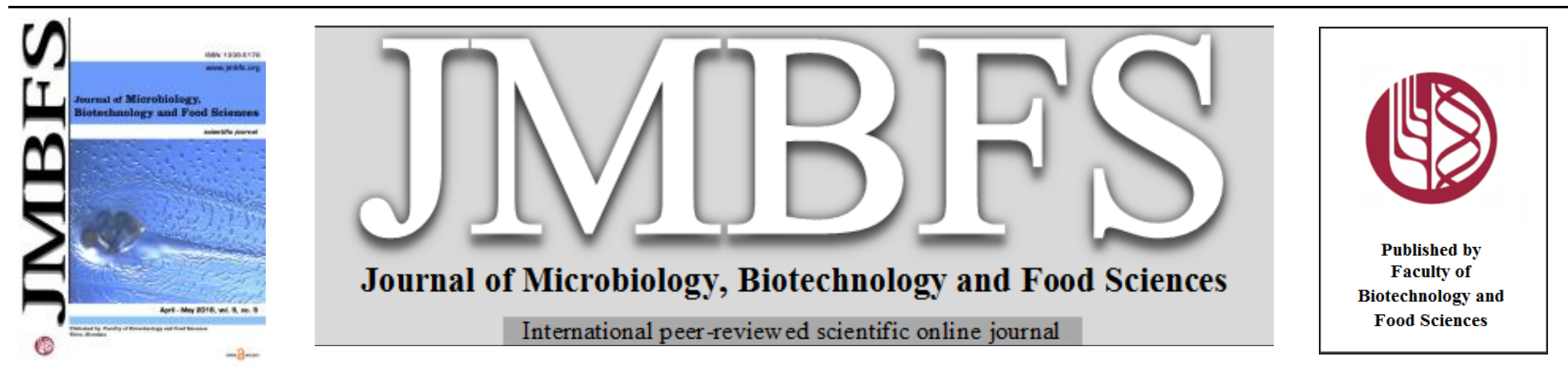

\title{
EFFECT OF ULTRASOUND AND THERMAL TREATMENT ON PECTIN METHYLESTERASE ACTIVITY IN PAPAYA (Carica papaya) JUICE
}

\author{
Villanueva-Tiburcio, J.E., ${ }^{1,2} *$ Vargas-Solórzano, J.W., ${ }^{3,1}$ González-Reynoso, O., ${ }^{2}$ Leandro-Laguna, C., ${ }^{4,1} \&$ Alfaro-Cruz, S.C. ${ }^{5}$
}

Address(es): Villanueva-Tiburcio J.E.

${ }^{1}$ Universidad Nacional Agraria de la Selva, Av. Universitaria Km. 1,5. Tingo María - Perú, Tel: +51(062)562342.

${ }^{2}$ Universidad de Guadalajara, Centro Universitario de Ciencias Exactas e Ingeniería, Boulevard Marcelino García Barragán \#1421, C.P. 44430 Guadalajara, Jalisco México, Tel:+52(33)13785900 ext. 27508.

${ }^{3}$ Universidade Federal Rural do Rio de Janeiro, Instituto de Tecnología, Rodovia Br 465 Km 7, CEP 23890-000, Seropédica, RJ - Brazil.

${ }^{4}$ Universidad Nacional Intercultural de la Amazonía, Yarinacocha - Perú.

${ }^{5}$ Universidad Nacional José Faustino Sánchez Carrión, Huacho - Perú.

*Corresponding author: juanedvi@yahoo.es

doi: 10.15414/jmbfs.2016.5.5.487-490

\section{ARTICLE INFO}

Received 3. 9. 2014

Revised 6. 4. 2015

Accepted 6. 1. 2016

Published 1. 4. 2016

Regular article

open 2 access

\section{ABSTRACT}

Among the pectic enzymes present in fruits and vegetables, pectin methylesterase (PME) is usually related to the loss of quality and it causes adverse effects on finished products. In this research, the kinetic of ultrasound and thermal treatments are evaluated in the PME activity in papaya juice. The results showed that the ultrasound treatment caused an increase in the catalytic activity up to $52 \%$. After a while, the catalytic activity decreased in $27 \%$ indicating that the ultrasound was not effective in the enzymatic inactivation, whereas the thermal treatment inactivated $71 \%$ of the PME. However, these results open perspectives to evaluate the effect of ultrasound and enhance the catalytic activity of enzymes of industrial interest.

Keywords: Ultrasound, pectin methylesterase, inactivation, papaya

\section{INTRODUCTION}

Fruit consumption is important in public health care because it reduces the risk of various cancers and it also helps to reduce obesity (de Bruijn, 2010). Therefore, the development of new technologies, to obtain minimal processed foods, retaining their nutritional and organoleptic qualities, are important issues in food the industries.

Pectin methylesterase (PME, EC3.1.1.11) is usually found in the cell-wall of plants, phytopathogenic fungi and bacteria; it catalyzes the hydrolysis of the methylester bonds, releasing methanol and pectin with free carboxyl groups ; PME also catalyzes the enzymatic de-esterification of pectin, decreasing its degree of methylation (DM). Therefore, the inactivation of endogenous PME in fruits is important to avoid a production of low methoxyl pectins (DM < $50 \%$ ), which could result in a decrease of the quality of fruit texture. On the other hand, in low-acid fruits, the presence of divalent ions such as calcium, interconnect pairs of carboxyl groups of different low methoxyl pectin chains, forming aggregation of pepectic substances, phenomena know as cloud loss of fruit juices (Croak and Corredig, 2006).

Mainly, the inactivation of PME is conducted using thermal process, with a negative impact on the product attributes. Prolonged treatment at high temperatures, such as those needed to sterilize low-acid vegetables can result in a partial or total pectin depolymerization, resulting in a texture degradation of fruits (Croak and Corredig, 2006). Several works inactivating fruit PMEs in combination with or whitout thermal processes such as high pressure, high intensity pulsed electric field, have been reported elsewhere (Castro et al., 2006; Espachs-Barroso et al., 2006; Guiavarc'h et al., 2005; Polydera et al., 2004; Velázquez-Estrada, et al., 2012; Wilińska et al., 2008). However, a few studies have been reported combining the thermal process and the ultrasound (Raviyan, et al., 2005; Terefe et al., 2009; Tiwari et al., 2009). The mechanism of enzyme inactivation by ultrasound treatment involves the formation, growth, and collapse of tiny gas bubbles or cavities in a liquid where the ultrasound waves travel through it (Raviyan et al., 2005). Most of the data regarding the inactivation of PME using ultrasound processes are conducted for tomato (Raviyan et al., 2005; Plaza et al., 2007), apple juice (Abid et al., 2014), carrots (Gamboa-Santos et al., 2012), orange juice (Tiwari et al., 2009), mango juice (Santhirasegaram et al., 2013), and cantaloupe melon juice
(Fonteles et al., 2012); from experiments conducted in various fruits, the researcher indicate that ultrasound has advantageous because of the reduction PME activity is in a short times and it does not have significant effects on vitamins content, $\mathrm{pH}$, sugars and phenolic compounds. In this context, the present study focuses on the kinetics of inactivation of PME by ultrasound and thermal treatment, in papaya juice.

\section{MATERIALS AND METHODS}

\section{Fruit samples and sample preparation}

The papaya fruits, were purchased in a wholesale food market in the city of Tingo María, Huánuco Perú. After, we proceeded according to the flowchart show in Figure 1. The operations are described below:

The fruit was washed with distilled water (GFL, D-30938 Burgwedel, Type 2004), removing all impurities attached on its surface. After it was performed peeled with stainless steel knives, by cutting lengthwise, seeds were separated with a stainless steel spoon. The pulp was obtained with the juicer (DeLonghi Duo System, Model: ROBOdiet).

After $5 \mathrm{~mL}$ of papaya pulp were packaged in glass tubes with screw caps. In this stage the $\mathrm{pH}$ was analyzed (OAKTON pH 1100), ${ }^{\circ}$ Brix (Labor MIN) and the titratable acidity to obtain the index of maturity of the product.

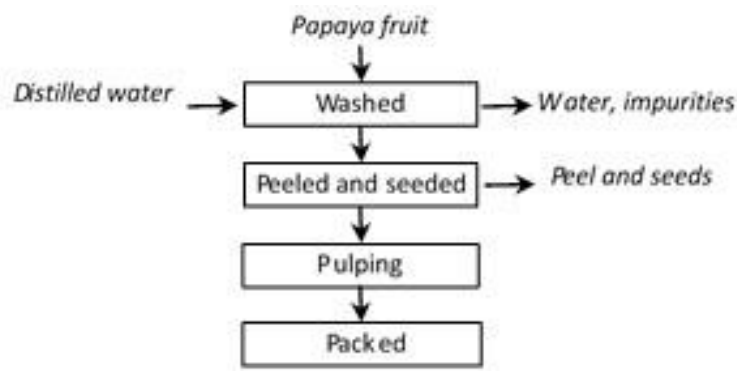

Figure 1 Flowchart of operations for obtain papaya juice 


\section{Ultrasonic treatmen}

The treatment was performed by placing the papaya pulp $(5 \mathrm{~mL})$ in glass tubes, within the ultrasound equipment (JAC Ultrasonic Lab. Companion Model: 1002) at different times $(1,2,3,4,5,6,8$ and $10 \mathrm{~min}$ at $40 \mathrm{kHz})$ the temperature of water in the ultrasound equipment was maintained at $27^{\circ} \mathrm{C}$. Then the tubes were immersed in a container containing crushed ice to stop the enzymatic reaction in the papaya juice. The samples were kept in the ice bath to measure the activity of the pectin methylesterase.

\section{Thermal treatment}

The glass tubes containing papaya pulp, were placed in a maria bath (GEMMYCO, Model: YCW-010E) in total immersion, then the maria bath was scheduled with a maximum temperature of $75.5^{\circ} \mathrm{C}$.

After that, samples were taken (papaya pulp tubes) at different times of thermal treatment (to intervals of $4 \mathrm{~min}$ for $56 \mathrm{~min}$ ) and immediately were immersed in a container containing crushed ice in order to stop the inactivation of PME by heat. Then, the pectin methylesterase activity was assessed.

\section{Measurement the activity of the pectin methylesterase (PME)}

Activity of pectin methylesterase (PME) was performed according to the method reported by Stoforos et al. (2002). In a titration vessel $42 \mathrm{~mL}$ of aqueous suspension of pectin $0.5 \%$ ( $\mathrm{pH} 7.0$ ), was added, then $15 \mathrm{~mL}$ of $\mathrm{NaCl}$ $(0.5 \mathrm{M})$ plus $2.8 \mathrm{~mL}$ deionized water. Then adjusted to $\mathrm{pH} 7.5$ with $\mathrm{NaOH}$ $(0.01 \mathrm{~N})$, the hydrolysis reaction was initiated by adding $200 \mu \mathrm{L}$ of the juice obtained from the papaya pulp (previously filtered to vacuum with Wattman paper No. 40). This was continuously titrated with $\mathrm{NaOH}(0.01 \mathrm{~N})$ for 30 min, recording the volume consumed during titration at $27 \pm 0.4{ }^{\circ} \mathrm{C}$, all samples were measured in triplicate. The enzymatic activity (AE), was calculated as follows:

$\mathrm{AE}=\frac{\mathrm{dV}_{\mathrm{NaOH}}}{\mathrm{dt}} \cdot \frac{\mathrm{N}_{\mathrm{NaOH}}}{\mathrm{V}_{\mathrm{sample}}}$

Eq. 1

Where AE: [ $\mu$ eq $\mathrm{H}^{+} /(\min . \mathrm{mL})$ ], $\mathbf{d} \mathbf{V}_{\mathbf{N a O H}} / \mathbf{d t}$ means, $\mathbf{N}_{\mathbf{N a O H}}$ is the Normality of Sodium Hydroxide and $\mathbf{V}_{\text {sample }}$ the volume used in the sample in $\mathrm{mL}$.

\section{Statistical analysis}

Statistical analyzes were performed using Statistica V8, the inhibition of activity PME subjected to an analysis of variance (ANOVA), with a level of 0.05

\section{RESULTS AND DISCUSSION}

\section{State of ripeness}

Fruit ripening in papaya (Carica papaya) varies widely in terms of skin color changes, pulp firmness and shelf life. However, yellow color in the fruit skin (Figure 2) has been used as a harvest index criterion to assure adequate ripening and maximum shelf life (Basulto et al., 2009). The maturity index is a measurement that can be used to determine if a fruit is mature (Fawole and Opara, 2013). The contents of titratable acids (TA) and hence the sugar/acid ratio (TSS/TA) is highly correlated with the maturity index (Reichel $\boldsymbol{e t} \boldsymbol{a l . , 2 0 1 0}$ ). It is known that the acidity in the papaya fruit increases during maturation, because increases its content of vitamin C, also increases in total soluble solids content (Serry, 2011). In the Table 1 are shows the results of evaluations conducted for the papaya pulp.

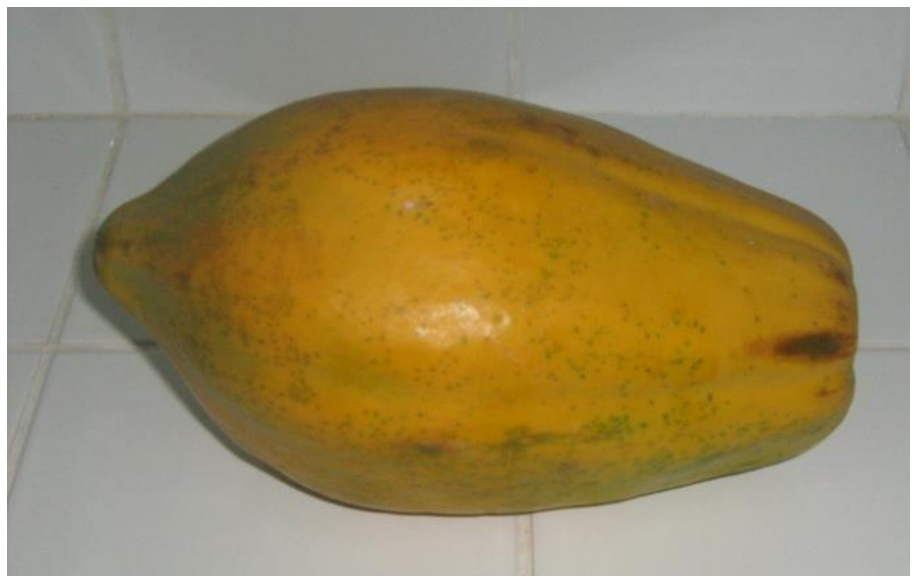

Figure 2 Fruit ripe of papaya (carica papaya)
Table 1 Analysis of $\mathrm{pH},{ }^{\circ}$ Brix, acidity titratable and maturity index ripe papaya pulp

\begin{tabular}{lc}
\hline \hline Analysis in papaya pulp & Means \\
\hline $\mathrm{pH}$ & $5,80 \pm 0,20$ \\
$\%$ Total soluble solids (TSS) & $11,00 \pm 0,96$ \\
$\%$ Acidity titratable & $(\mathrm{TA})$ \\
Maturity index (TSS/TA) & $2,18 \pm 0,34$ \\
\hline${ }^{1}$ Data expressed as mean \pm standard deviation, $\mathrm{n}=3 .{ }^{\gamma}$ Expressed in \% citric
\end{tabular}
acid

The maturity index (TSS/TA), by which we measured the physiological maturity of the fruit ripens, was $5.10 \pm 0.50$. That indicates the stage of development of the fruit, is usually associated with consumer acceptation (Blankenship et al., 1997).

\section{Kinetic of inactivation by ultrasound and thermal treatment of PME}

Pectin methylesterase (PME; E.C.3.1.1.11) is one of the enzymes present in many fruits and it usually bring negative consequences on the characteristics of the fruit (Yeom et al., 2002), it is an endogenous pectic pectin enzyme found presents in many fruits that de-esterifies the methyl group of pectin and converts it into low methoxy pectin or pectic acids (Giner et al., 2000). In this experiment, we evaluated the effect of ultrasound and the thermal treatment with respect to the time for inactivating the PME.

Regarding the results of the effects of ultrasound treatments on enzyme activities of PME in papaya juice is show in the Figure 3, the inhibition of PME by ultrasound were kept at the constant water temperature of $27^{\circ} \mathrm{C}$ and, the ultrasound power $(40 \mathrm{kHz})$, inactivation kinetics shown two phases; one phase comprises the activity increasing of the PME from 2 to 4 minutes, until the initial enzyme activity was $3.8 \mu \mathrm{eqH} \mathrm{H}^{+} /(\min \mathrm{mL})$ at $4 \mathrm{~min}$ showed that the maximum activity was $5.8 \mu \mathrm{eqH} \mathrm{H}^{+} /(\mathrm{min} \mathrm{mL})$ which corresponds to an increase of $52 \%$, this behavior is probably due by the cavitation bubbles that enhance the activity of the enzyme (Subhedar and Gogate, 2014), producing changes in the enzyme conformation mainly attributed to Trp, Tyr and Phe residues, particularly to Trp residue, could induce molecular unfolding of protein, destroying hydrophobic interactions of protein molecules, causing that hydrophobic groups and regions inside the molecules are exposed to the outside (Jia et al., 2010). Subsequently, from minute 4 to 5 , it was observed a decreasing in the enzyme activity up to $2.6 \mu \mathrm{eqH}^{+} /(\mathrm{min} \mathrm{mL})$ equivalent to $27 \%$ compared with the initial enzyme activity. Ultrasound can rupture the weak linkages like hydrogen bonds or Van der Waals interactions and bring conformational changes in the protein structure (Bashari et al., 2013) and probably destroying hydrophobic interactions of protein molecules (Gülseren et al., 2007). These events cause the enzymatic inactivation (López and Burgos, 1995; Cullen et al., 2012).

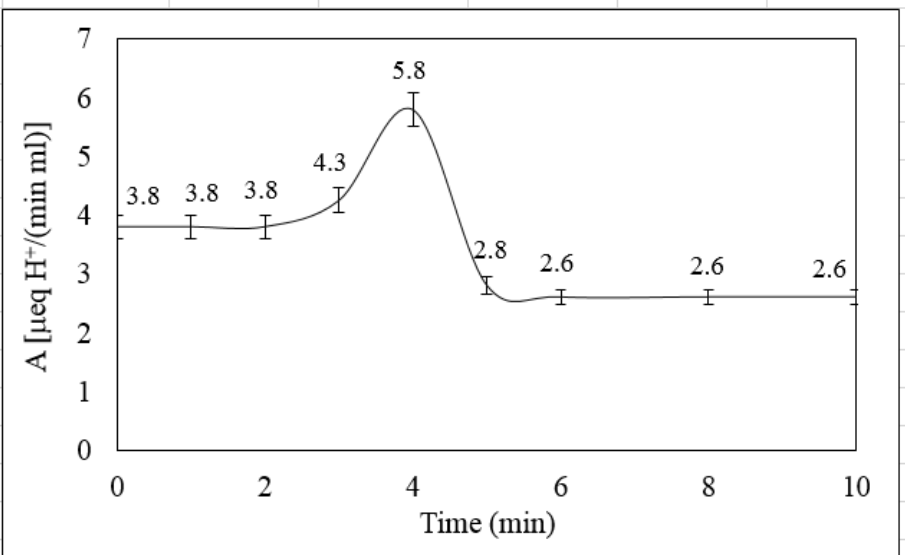

Figure 3 Kinetic of inactivation of PME in papaya juice by ultrasound (40 $\mathrm{KHz}$ )

Similar results were obtained by Gamboa-Santos $\boldsymbol{e t}$ al. (2012), who evaluated the inactivation of PME at $20 \mathrm{kHz}$, in carrots ground and sliced. They reported a decrease of the PME activity of $49.0 \pm 3.0 \%$ treated at $35^{\circ} \mathrm{C}$ by $60 \mathrm{~min}$ while the carrot pieces obtained in maximum decrease to $53.5 \pm 2.1 \%$ at $70{ }^{\circ} \mathrm{C}$ for $15 \mathrm{~min}$ Meanwhile Wu et al. (2008), they inactivated PME by thermosonication in tomato juice $(24 \mathrm{kHz})$ at different times and temperatures, as a result for inactivation of $90 \% \mathrm{PME}$ were required $41.8,11.7$ and 4.3 minutes to $60{ }^{\circ} \mathrm{C}, 65$ ${ }^{\circ} \mathrm{C}$ and $70{ }^{\circ} \mathrm{C}$, respectively. An important aspect concerning the short PME inhibition refers de Assis et al. (2000), who describe that this behavior may be related to the presence of isoenzymes, or possible aggregates which form during the process of sonication and that is added to protect the enzyme decreasing the damage to the protein structure. It is also known that the active site of the PME is situated in the outer part of the $\beta$-helix of the PME (Giovane et al., 2004). The results obtained demonstrate the relevance of ultrasound applications in the 
increasing and decreasing of activity of the PME

On the other hand, the Figure 4 showed that the kinetics inhibition of PME by effect of temperature in function of time. The increasing temperature and time produced the reduction of PME activity. Arising from this, the mathematical model was obtained that explain the inhibition of PME activity (Equation 2).

$\mathrm{AE}=7.1-0.15 \mathrm{~T}+0.09 \mathrm{t} ; \mathrm{R}^{2}=0.99$

Where $\mathbf{T}$ represents the Temperature in $\left({ }^{\circ} \mathrm{C}\right)$ and $\mathbf{t}$ is the time in unities of (min).

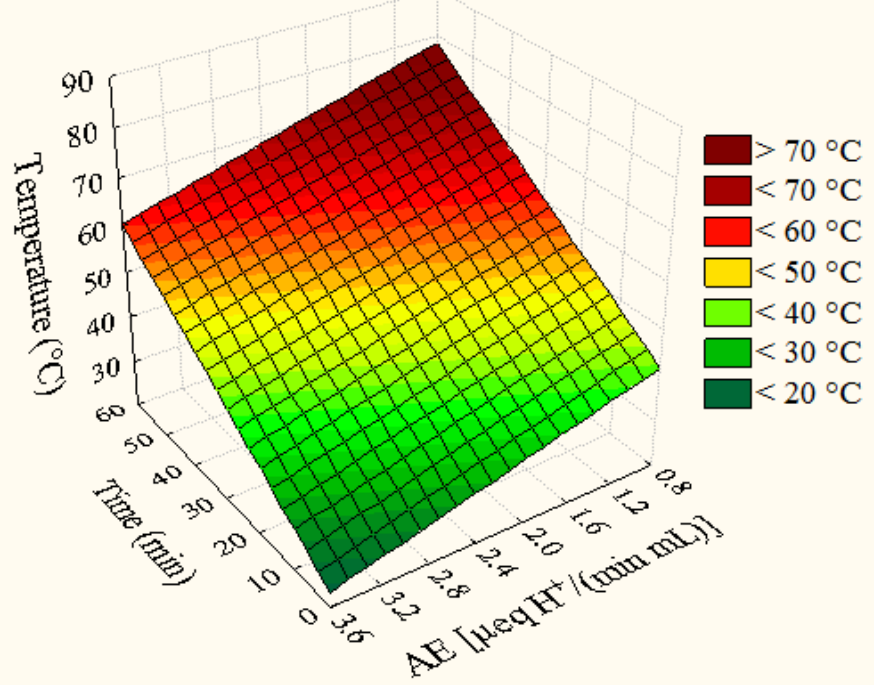

Figure 4 Enzymatic activity in papaya juice as function of time and temperature of thermal treatment

The effect of temperature, generated by the water bath, was effective in reducing the enzymatic activity of the PME, we obtained $71 \%$ inactivation at 56 minutes $75.5{ }^{\circ} \mathrm{C}$, at atmospheric pressure. Cano et al. (1997), reported a maximum inactivation of PME (25\% reduction of the initial activity) for the treatment of orange juice to $200 \mathrm{MPa}$ and $30^{\circ} \mathrm{C}$ the tested range was from 50 to $400 \mathrm{MPa}$ and 20 to $60{ }^{\circ} \mathrm{C}$. Meanwhile, Stoforos et al. (2002) evaluated the inhibition of PME in tomato pulp, applying heat $\left(60-75^{\circ} \mathrm{C}\right)$ and pressure of $0-800 \mathrm{MPa}$, obtaining greater inactivation at $75{ }^{\circ} \mathrm{C}$ and atmospheric pressure, also reported an increase of inactivation at higher pressures that $700 \mathrm{MPa}$ at $75^{\circ} \mathrm{C}$, and demonstrated that the loss of enzyme activity may occur via two different mechanisms, one mechanism may be associated with the temperature and the other with the pressure induced. Ly-Nguyen et al. (2002), extracted and purified PME from carrots and evaluated the effect of heat treatment, after $10 \mathrm{~min}$ and $65{ }^{\circ} \mathrm{C}$ of treatment the PME activity was not detected. While de Assis et al. (2000) required $98 \mathrm{~min}$ and $110{ }^{\circ} \mathrm{C}$ to inactivate the $\mathrm{PME}$ in acerola. Our results obtained include greater time and temperature $\left(56 \mathrm{~min}, 75.5^{\circ} \mathrm{C}\right)$ to reduce by $71 \%$ the activity of the PME. It is clear that among the various sources of obtaining PME, the inactivation have different temperatures (de Assis et al, 2000; Wu et al, 2008).

\section{CONCLUSION}

The effect of increasing temperature over time, caused the reduction in high percentage of the PME activity, however the kinetics of sonication has positive effect on PME activity because partly increased the activity to obtain $52 \%$ in 4 min of treatment, subsequently the effect of inactivation decreased $27 \%$ compared with the untreated sample at initial time. The increase in enzyme activity by the ultrasound open perspectives for increases the capacity of catalysis in other enzymes of industrial interest.

Acknowledgment: The authors thank PhD Luis Condezo Hoyos, Washington State University for his suggestions in this research.

\section{REFERENCES}

ABID, M., JABBAR, S., HUA, B., HASHIM, M.M., WUA, T., LEI, SH., KHAN, M.A., ZENG, X. 2014. Thermosonication as a potential quality enhancement technique of apple juice. Ultrasonics Sonochemistry, 21(3), 984-990. http://dx.doi.org/10.1016/j.ultsonch.2013.12.003

BASULTO, F.S., SAURI, D.E., ESPADAS, Y G.F., DÍAZ, P.R., LARQUÉ, S.A., SANTAMARÍA J.M. 2009. Postharvest ripening and maturity indices for Maradol papaya. Interciencia, 34(8), 583-588.
BASHARI, M., EIBAID, A., WANGA, J., TIAN, Y., XU, X., JIN, Z. 2013. Influence of low ultrasound intensity on the degradation of dextran catalyzed by dextranase. Ultrasonics Sonochemistry, 20(1), 155-161. http://dx.doi.org:10.1016/j.ultsonch.2012.06.010

BLANKENSHIP, S.M., PARKER, M., UNRATH, R. 1997. Use of maturity indices for predicting poststorage firmness of "Fuji" apples. HortScience, 32(5), 909-910.

CANO, M.P., HERNÁNDEZ, A., DE ANCOS, B. 1997. High pressure and temperature effects on enzyme inactivation in strawberry and orange products. Journal of Food Science, 62(1), 85-88. http://dx.doi.org/10.1111/j.1365-2621.1997.tb04373.x

CASTRO, S.M., VAN LOEY, A., SARAIVA, J.A., SMOUT, CH., HENDRICKX, M. 2006. Inactivation of pepper (Capsicum annuum) pectin methylesterase by combined high-pressure and temperature treatments. Journal of Food Engineering, 75(1), 50-58. http://dx.doi.org/10.1016/j.jfoodeng.2005.03.050

CROAK, S., CORREDIG, M. 2006. The role of pectin in orange juice stabilization: Effect of pectin methylesterase and pectinase activity on the size of cloud particles. Food Hydrocolloids, 20(7), 961-965. http://dx.doi.org/0.1016/j.foodhyd.2005.10.016

CULLEN, P.J., TIWARI, B.K., VALDRAMIDIS, V. 2012. Novel thermal and non-thermal technologies for fluid foods. Publisher: Academic Press, 542 p. ISBN 978-0123814708.

DE ASSIS, S.A., LIMA, D.C., DE FARIA OLIVEIRA, O.M.M. 2000 Acerola's pectin methylesterase: studies of heat inactivation. Food Chemistry, 71(4), 465-467. http://dx.doi.org/10.1016/S0308-8146(00)00173$\underline{4}$

DE BRUIJN, G.-J. (2010). Understanding college students' fruit consumption. Integrating habit strength in the theory of planned behaviour. Appetite, 54(1), 16-22. http://dx.doi.org/10.1016/j.appet.2009.08.007

ESPACHS-BARROSO, A., LOEY, A.V., HENDRICKX, M., MARTÍNBELLOSO, O. 2006. Inactivation of plant pectin methylesterase by thermal or high intensity pulsed electric field treatments. Innovative Food Science \& Emerging Technologies, $\quad 7(1-2), \quad 40-48$ http://dx.doi.org/10.1016/j.ifset.2005.07.002

FAWOLE, O.A., OPARA, U.L. 2013. Developmental changes in maturity indices of pomegranate fruit: a descriptive review. Scientia Horticulturae, 159, 152-161. http://dx.doi.org/10.1016/j.scienta.2013.05.016

FONTELES, T.V., MAIA COSTA, M.G., TIBÉRIO DE JESUS, A.L. ALCÂNTARA DE MIRANDA, M.R., NARCISO FERNANDES, F.A. RODRIGUES, S. 2012. Power ultrasound processing of cantaloupe melon juice: effects on quality parameters. Food Research International, 48(1), 41 48. http://dx.doi.org/10.1016/j.foodres.2012.02.013

GAMBOA-SANTOS, J., MONTILLA, A., SORIA, A.C., VILLAMIEL. M. 2012. Effects of conventional and ultrasound blanching on enzyme inactivation and carbohydrate content of carrots. European Food Research and Technology, 234(6), 1071-1079. http://dx.doi.org/10.1007/s00217-0121726-7

GINER, J., GIMENO, V., ESPACHS, A., ELEZ, P., BARBOSA-CÁNOVAS, G.V., MARTÍN, O. 2000. Inhibition of tomato (Licopersicon esculentum Mill.) pectinmethylesterase by pulsed electric fields. Innovative Food Science \& Emerging Technologies, 1(1), 57-67. http://dx.doi.org/10.1016/S1466 8564(00)00003-5

GIOVANE, A., SERVILlO, L., BALESTRIERI, C., RAIOLA, A., D'AVINO, R., TAMBURRINI, M., CIARDIELLO, M.A., CAMARDELLA, L. 2004. Pectin methylesterase inhibitor. Biochimica et Biophysica Acta, 1696(2), 245-252. http://dx.doi.org/10.1016/j.bbapap.2003.08.011

GUIAVARC'H, Y., SEGOVIA, O., HENDRICKX, M., VAN LOEY, A. 2005. Purification, characterization, thermal and high-pressure inactivation of a pectin methylesterase from white grapefruit (Citrus paradisi). Innovative Food Science \& Emerging Technologies, 6(4), 363-371. http://dx.doi.org/10.1016/j.ifset.2005.06.003

GÜLSEREN, I., GÜZEY, D., BRUCE, B.D., WEISS, J. 2007. Structural and functional changes in ultrasonicated bovine serum albumin solutions. Ultrasonics Sonochemistry, 14(2), 173-183. http://dx.doi.org/10.1016/j.ultsonch.2005.07.006 JIA, J., MA, H., ZHAO, W., WANG, Z., TIAN, W., LUO, L., HE, R. 2010. The use of ultrasound for enzymatic preparation of ACE-inhibitory peptides from wheat germ protein. Food Chemistry, 119(1), 336-342. http://dx.doi.org/10.1016/j.foodchem.2009.06.036

LÓPEZ, P., BURGOS, J. 1995. Lipoxygenase inactivation by manothermosonication: effects of sonication physical parameters, $\mathrm{pH}, \mathrm{KCl}$. Sugars, glycerol and enzyme concentration. Journal of Food Agricultural and Food Chemistry, 43(3), 620-625. http://dx.doi.org/10.1021/jf00051a012

LY-NGUYEN, B., VAN LOEY, A.M., FACHIN, D., VERLENT, I., INDRAWATI, I. and HENDRICKX, M.E. 2002. Partial purification, characterization, and thermal and high-pressure inactivation of pectin methylesterase from carrots (Daucus carrota L.). Journal of Agricultural $\begin{array}{llll}\text { and Food Chemistry, 50(19), } & \text { 5437-5444. }\end{array}$ http://dx.doi.org/10.1021/jf011666v 
PLAZA, L., DUVETTER, T., MONFORT, S., CLYNEN, E., SCHOOFS, L., VAN LOEY, A.M., HENDRICKX, M.E. 2007. Purification and thermal and high-pressure inactivation of pectinmethylesterase isoenzymes from tomatoes (Lycopersicon esculentum): a novel pressure labile isoenzyme. Journal of Food Agricultural and Food Chemistry, 55(22), 9259-9265. http://dx.doi.org/10.1021/jf0718502

POLYDERA, A.C., GALANOU, E., STOFOROS, N.G., TAOUKIS, P.S 2004. Inactivation kinetics of pectin methylesterase of greek navel orange juice as a function of high hydrostatic pressure and temperature process conditions. Journal of Food Engineering, 62(3), 291-298. http://dx.doi.org/10.1016/S0260-8774(03)00242-5

RAVIYAN, P., ZHANG, Z., FENG, H. 2005. Ultrasonication for tomato pectinmethylesterase inactivation: effect of cavitation intensity and temperature on inactivation. Journal of Food Engineering, 70(2), 189-196. http://dx.doi.org/10.1016/j.jfoodeng.2004.09.028

REICHEL, M., CARLE, R., SRUAMSIRI, P., NEIDHART, S. 2010 Influence of harvest maturity on quality and shelf-life of litchi fruit (Litchi chinensis Sonn.). Postharvest Biology and Technology, 57(3), 162-175. http://dx.doi.org/10.1016/j.postharvbio.2010.04.005

SANTHIRASEGARAM, V., RAZALI, Z., SOMASUNDRAM, CH. 2013. Effects of thermal treatment and sonication on quality attributes of Chokanan mango (Mangifera indica L.) juice. Ultrasonics Sonochemistry, 20(5), 1276-1282. http://dx.doi.org/10.1016/j.ultsonch.2013.02.005

SERRY, N.K.H. 2011. Postharvest handling of solo papaya fruits harvested at different maturity stages. American-Eurasian Journal of Agricultural \& Environmental Sciences, 11(2), 205-210.

STOFOROS, N.G., CRELIER, S., ROBERT, M.-C. and TAOUKIS, P.S. 2002. Kinetics of tomato pectin methylesterase inactivation by temperature and high pressure. Journal of Food Science, 67(3), 1026-1031. http://dx.doi.org/10.1111/j.1365-2621.2002.tb09448.x

SUBHEDAR, P.B., GOGATE, P.R. 2014. Enhancing the activity of cellulase enzyme using ultrasonic irradiations. Journal of Molecular Catalysis B. Enzymatic, 101, 108-114. http://dxdoi.org/10.1016/j.molcatb.2014.01.002

TEREFE, N.S., GAMAGE, M., VILKHU, K., SIMONS, L., MAWSON, R., VERSTEEG, C. 2009. The kinetics of inactivation of pectin methylesterase and polygalacturonase in tomato juice by thermosonication. Food Chemistry, 117(1), 20-27. http://dx.doi.org/10.1016/j.foodchem.2009.03.067

TIWARI, B.K., MUTHUKUMARAPPAN, K., O'DONNELL, C.P., CULLEN, P.J. 2009. Inactivation kinetics of pectin methylesterase and cloud retention in sonicated orange juice. Innovative Food Science \& $\begin{array}{llll}\text { Emerging Technologies, } & 10(2), & 166-171 .\end{array}$ http://dx.doi.org/10.1016/j.ifset.2008.11.006

VELÁZQUEZ-ESTRADA, R.M., HERNÁNDEZ-HERRERO, M.M., GUAMIS-LÓPEZ, B., ROIG-SAGUÉS, A.X. 2012. Impact of ultra high pressure homogenization on pectin methylesterase activity and microbial characteristics of orange juice: a comparative study against conventional heat pasteurization. Innovative Food Science \& Emerging Technologies, 13 , 100-106. http://dx.doi.org/10.1016/j.ifset.2011.09.001

WILIŃSKA, A., DE FIGUEIREDO RODRIGUES, A.S., BRYJAK, J., POLAKOVIC, M. 2008. Thermal inactivation of exogenous pectin methylesterase in apple and cloudberry juices. Journal of Food Engineering, 85(3), 459-465. http://dx.doi.org/10.1016/j.jfoodeng.2007.08.009

WU, J., GAMAGE, T.V., VILKHU, K.S., SIMONS, L.K., MAWSON, R. 2008. Effect of thermosonication on quality improvement of tomato juice. Innovative Food Science \& Emerging Technologies, 9(2), 186-195. http://dx.doi.org/10.1016/j.ifset.2007.07.007

YEOM, H.W., ZHANG, Q.H. and CHISM, G.W. 2002. Inactivation of pectin methyl esterase in orange juice by pulsed electric fields. Journal of Food Science, 67(6), 2154-2159. http://dx.doi.org/10.1111/j.13652621.2002.tb09519.x 